\title{
Far beyond the Line: Corsairs, Privateers, Buccaneers, and Invading Settlers in Cuba and the Caribbean (1529-1670) ${ }^{1}$
}

\author{
by \\ Luis Martínez-Fernández \\ University of Central Florida
}

Tiene el tercer Filipo, Rey de España,

la ínsula de Cuba, o Fernandina, en estas Indias que el oceano baña, rica de perlas y de plata fina: aqui del Anglia, Flandes y Bretaña á tomar vienen puerto en su marina muchos navios á trocar por cueros sedas y paños, y á llevar dineros ${ }^{2}$.

Silvestre de Balboa

Que es mi barco mi tesoro, Que es mi Dios la libertad, Mi ley, la fuerza y el viento, Mi única patria, la mar $^{3}$.

José de Espronceda

1 This essay was researched and written under the auspices of Project of the Plan Nacional de MINECO (España) HAR2012-37445-C03-03.

${ }^{2}$ De Balboa, 1970: 55.

${ }^{3}$ De Espronceda, 1999: 72-74. 
This essay connects the course of war and peace in Europe with a variety of forms of European incursion in the Caribbean during the $1500 \mathrm{~s}$ and $1600 \mathrm{~s}$. With special attention to Cuba, it traces the emergence and evolution of piracy and privateering as well as European colonial expansion by settlers and buccaneers. This essay also provides a systematic analysis of how belligerence in the Old World impacted the Caribbean. Lastly, it explores Spain's efforts to protect its colonies through fortifications, fleet systems, and increased military presence.

Key words: buccaneers; Caribbean: Cuba; Colonization; Fleet system; fortifications; pirates; Wars.

This is a synthetic interpretative essay on non-Hispanic intrusions and invasions in the Spanish-claimed Caribbean, particularly Cuba, during the sixteenth century and first seven decades of the seventeenth. It traces the complex -oftentimes chaotic- interplay between war and peace in Europe and conflicts in the Caribbean region, which historian Eric Williams aptly named "the cockpit of Europe." It was a cockpit, indeed, but one that played by its own set of rules. The Caribbean thus, as Richard Dunn put it, "was beyond the line." It was a region in which Europeans "flout[ed] European treaty obligations"; and equally disconcertingly, where they "flout[ed] European social conventions," acting violently and behaving viciously. This work also builds on Franklin W. Knight's typology of Caribbean colonies, with one pole represented by "colonies of settlement" and the other by "colonies of exploitation." 4

This contribution to the expanding field of Atlantic history is a systematic analysis of the relation between European wars and a variety of forms of aggression in the Caribbean. It demonstrates that while war in Europe often translated into bellicose actions in the Caribbean, piracy, privateering, and buccaneering were endemic to the region and had a logic of their own that was manifested in alliances among foreigners whose countries were at war in Europe and also in violent exchanges among people whose home countries were at peace.

The longue durée nature of this work allows a broad perspective that demonstrates changes over time, including the rise and fall of wars motivated by religion, the emergence of commercial wars, shifting levels of loyalty and obedience to orders arriving from Europe, and the ascendance and decline among Europe's contending nations.

\footnotetext{
${ }^{4}$ Dunn, 1973: 11-12. Knight, 1990: 74-76. Williams, 1970, chapter 7.
} 
Throughout most of the period beginning in the $1510 \mathrm{~s}$, continuing during the balance of the sixteenth century, and throughout the next hundred years, Spain remained in an on-and-off state of war with France, England, the Netherlands, and other European nations, which in turn intermittently clashed against each other. The endless cacophony of war echoed loudly in Cuba and throughout the Caribbean, oftentimes more stridently than in Europe, as pirates, corsairs, privateers, buccaneers, and later regular naval and land forces attacked Spanish vessels and colonial possessions. Smuggling, sometimes peaceful, sometimes violent, was another form of intrusion by Spain's European foes and friends alike.

Yes, the Caribbean became Europe's tropical cockpit but one in which cocks fought when, how, and against whom they wanted. It was a cockpit with a life of its own, located "beyond the line." Not the line agreed upon by Spain and Portugal in the Treaty of Tordesillas (1494), which granted Spain claim to the entire Caribbean and most of the yet-unknown continental Americas. That line soon washed away as other European nations began to explore, attack, and settle the Americas. In contrast, Dunn's imaginary line persisted for centuries, a line beyond which European sailors, traders, settlers, and soldiers acted in ways that would have been unacceptable in Europe.

The consolidation of strong, expansive, centralized monarchies was actually financed by European exploitation of the New World's colonies, both directly, as in the case of Spain, and indirectly, by raiding bullion and other valuables from Spanish vessels and colonial ports. Modern monarchies like those of Spain's Charles I (1516-1556), England's Henry VIII (1509-1547), and France's Francis I (1515-1547) set in motion vicious circles of belligerence: draining wars produced financial strain, which in turn led to further conflagrations in a quest for bounty to pay debts and finance even more wars. Among the reasons for the continuous state of war that ripped Europe apart were disputes over royal succession, shifting dynastic alliances, balance-ofpower considerations, and expansionist ambitions for territorial control and commercial and navigational dominance. Spain's insistence on keeping the Caribbean as a mare clausum infuriated and pushed to action other Europeans seeking to benefit from the riches and commercial opportunities offered by the New World that was being unveiled before Europe's eyes.

Roughly coinciding with the age of conquest and colonization was the emergence and spread of Protestantism and the Roman Catholic Church's militant reaction to it as manifested through the Counterreformation, a movement led by Spain. Thus, religion played a crucial ideological role during the 1500s, with northern European Protestant and southern European Catholic armies slaughtering each other while praying to the same God. Sharing a 
common faith solidified dynastic and military alliances, but at some junctures, Protestant and Catholic kingdoms and states set religious difference aside and forged alliances with governments of different faiths. The period's most striking case was the 1530s alliance between Catholic France and the Muslim Ottoman Empire in opposition to the Catholic Hapsburg Empire. Such cross-faith alliances became even more common during the seventeenth century. Internal wars of religion also ravaged several European countries, France and Bohemia for example, and beyond the line throughout the Caribbean.

The 1500s was also a period of accelerated socioeconomic transformation. Following centuries of inward-looking feudalism during which control over land was the base of economic, social, and political power, wealth accumulated from the Americas created powerful mercantile and financial elites in Europe, whose power derived from trade, navigation, banking, and manufacturing. Bullion gradually displaced land as the most important measure of wealth and power. Capital that had been accumulated in the Americas and transported through the Caribbean from bullion, export crops and the exploitation of slaves became the primary engine for Europe's robust capitalist surge, which displaced feudalism as the dominant economic system. Thus, the Caribbean became a major stage for commercial and economic competition, largely played out by pirate and corsair actions against Spain's ports and vessels.

Crossing the line manifested itself in the nonobservance of European treaties. While in Europe, peace usually meant peace; in the Caribbean, peace seldom meant that. Even when truces were negotiated and peace treaties were signed, pirates, privateers, and buccaneers continued to plunder and pillage throughout the region.

While often used interchangeably, the words pirate, privateer, corsair, and buccaneer mean different things. The term pirate is broadly used to define those who plundered vessels on the high seas and raided ports and harbors. In its most specific definition, the word applies only to those booty-seekers who operated without license or sanction from a particular nation. Pirates were lawless and stateless predators. Privateers, for their part, carried out acts of piracy with special charters from their respective monarchs, and were generally less brutal than their unlicensed counterparts. When privateers worked for a private company such as the Dutch West India Company, investors received dividends from successful raids. Privateers operated with different degrees of loyalty and obedience to the monarchs who granted them privateering charters. In some instances, they were treated similarly to regular soldiers and were even allowed to use royal vessels. At times they ignored their monarch's commands, fighting in times of peace and attacking neutral nations. Corsair means roughly the same but is often applied to those licensed by the French 
Crown. Buccaneer is yet another related term. With their name originating in the Taino term bucan, meaning a wood-and-stick structure on which meat is grilled, dried, or smoked, buccaneers were originally wild cattle hunters who settled in various points of the Caribbean, leading a mostly land-based existence. Decades later, as they realized how profitable piracy was, they became increasingly maritime. They turned amphibious and, as Philip Gosse put it, converted "from butchers of cattle into butchers of men." ${ }^{5}$ Like pirates, buccaneers were stateless and conducted raids against vessels and on foreign coastal settlements. Their ties to their respective monarchs were loose and they operated with great autonomy.

All that said, as Manuel Lucena Salmoral explains, these categories were fluid and often overlapping. The line between piracy and corsair activities was often blurred. Buccaneers became outright pirates and vice versa. Pirates became privateers, once licensed, and reverted to piracy upon the revocation of their licenses. ${ }^{6}$ Sixteenth-and seventeenth-century Spaniards, for their part, made no distinction between pirates and privateers and even smugglers. All of them received stern sentences when captured.

European incursions in the Spanish Caribbean during the sixteenth and seventeenth centuries unfolded along distinct but overlapping stages that roughly mirrored the course of Spain's conflicts with other European powers: first a French corsair phase (1521-1559), then an English aggressive contraband phase (1558-1567), followed by an English piratical phase (1568-84), and an English privateering phase (1585-1603). Then came two periods of intense Dutch piracy and privateering (1594-1609, 1620-1648). Beginning in the $1620 \mathrm{~s}$ and 1630s, non-Hispanic privateers, traders, and settlers established permanent colonies and trading posts on islands neglected by Spain. Such colonies spread throughout the Caribbean, from the Bahamas in the North West to Tobago in the South East. In addition, beginning in the 1620s, French and English buccaneers settled in places like the island of Tortuga, the northern and western coasts of Hispaniola, and later in Jamaica.

\section{French Wars and Huguenot Corsairs (1521-1559)}

During the first three-quarters of the sixteenth century, matters of balance of power and dynastic succession weighed heavily on the course of European diplomacy and war. Europe's largest and most powerful kingdoms, France and

\footnotetext{
5 Gosse, 2007: 144.

${ }^{6}$ Lucena Salmoral, 1992: 33-37.
} 
Spain, were the continent's staunchest rivals. Tensions increased after 1516, when the kingdoms of Castile, Leon, and Aragon were formally unified under Charles I of Spain, who three years later expanded his domains after his election as Holy Roman Emperor. Now he ruled over the continent's largest and most powerful confederation of kingdoms, whose territories menacingly surrounded France, like a wide-open mouth about to devour it. In 1521, France went to war with the Holy Roman Empire. Spanish troops routed French armies in France, the Italian Peninsula, and elsewhere, forcing the French Crown to surrender in 1526 and again in 1529. The Italian Wars, as the French-Spanish wars came to be known, reignited in 1536 and again in 1542. Intermittent warring between the Valois monarchy and the Habsburg Empire continued until 1559.

French corsair attacks began in the early 1520 s, as soon as France declared war on Spain in 1521. At the time, prodigious treasures from Mexico began to cross the Atlantic en route to Spain. French monarch Francis I challenged Spain's exclusivist claims to the New World and its wealth, demanding to see "the clause in Adam's will which excluded me from my share when the world was being divided." 7 Giovanni da Verrazzano (aka Jean Florin) led the first recorded French corsair attack against Spanish vessels carrying treasures from the New World. In 1523, off the Cape of St. Vincent, Portugal, his vessels captured two Spanish ships laden with a fabulous treasure consisting of 70,000 ducats worth of gold, large quantities of silver and pearls, and 25,000 pounds of sugar, a much-treasured commodity at the time. ${ }^{8}$ The first recorded incursion in the Caribbean happened in 1528, when a lone French corsair vessel appeared off the coast of Santo Domingo and its crew sacked the village of San Germán on the western coast of Puerto Rico. ${ }^{9}$

In the mid-1530s, corsairs, some Catholic but most of them Protestant (Huguenot), began routinely attacking Spanish vessels and raiding Caribbean ports and coastal towns; the most coveted were Santo Domingo, Havana, Santiago, and San Germán. Corsair port raids in Cuba and elsewhere in the region usually followed the rescate (ransom) model, whereby the aggressors seized villages and cities, kidnapped local residents, and demanded payment for their release. If there were no hostages, corsairs demanded ransoms in exchange for sparing towns from destruction. Whether ransoms were paid or not, corsairs looted, committed unspeakable violence against their victims, desecrated churches and holy images, and left smoldering reminders of their incursions.

\footnotetext{
7 Hanke, 1949: 148.

8 Brevoort, 1721: 94. Lane, 1998: 18.

9 Hoffman, 1980: 38.
} 
In 1536, France and Spain went to war again and French corsairs launched a series of attacks on Spanish Caribbean settlements and ships. The next year, a corsair vessel appeared in Havana and demanded a 700-ducat rescate. Spanish men-of-war arrived soon and scared off the intruding vessel, which returned soon thereafter to demand yet another rescate. Santiago was also victim of an attack that year, and both cities endured raids yet again in $1538 .{ }^{10}$ The waters off Cuba's northwest became particularly attractive to pirates as commercial vessels returning to Spain had to squeeze through the 90-mile-long strait between Key West and Havana. In 1537-1538, corsairs captured and sacked nine Spanish vessels. ${ }^{11}$

While France and Spain were at peace until 1542, beyond-the-line corsair activity continued. When war erupted again, it echoed once more in the Caribbean. A particularly vicious French corsair attack took place in Havana in 1543. It left a gory toll of 200 killed Spanish settlers. In all, between 1535 and 1563, French corsairs carried out around sixty attacks against Spanish settlements and captured over seventeen Spanish vessels in the region (1536-1547). ${ }^{12}$

Spain developed a mostly defensive military strategy. It responded by fortifying and militarizing Havana and other port cities. Cuba's Captain-General Hernando de Soto was charged with the task of leading military construction projects. Construction of the port city's first fortress, later known as la Fuerza Vieja, began in 1539 and ended in 1540.

Another defensive mechanism was the practice of having merchant vessels cross the Atlantic in convoys escorted by naval ships to reduce the chances of being captured by corsairs. This practice began in the mid-1520s and was formally organized in the $1560 \mathrm{~s}$. While the fleet system varied over time, it generally included one convoy leaving Spain in April and another one in August, both laden with European products. The final destination of the first one, known as Fleet of New Spain, was Veracruz; it returned with American and Asian products such as silver, dyes, precious woods, and silk. The second one, Galleons of Tierra Firme, had its final call in Nombre de Dios, Panama. Havana was privileged by the fleet system because all returning ship convoys had to meet in Havana and depart together for Europe. ${ }^{13}$ The system had advantages and disadvantages. By sailing all at once with the protection of Spanish men-of-war, vessels crossing the Atlantic were better prepared to avoid and confront corsair and pirate attacks; however, the system was cumbersome, rigid, and slow, and a single storm or successful attack made for greater losses of ships and cargoes.

\footnotetext{
${ }^{10}$ Lane, 1998: 21.

${ }^{11}$ Hoffman, 1980: 26.

12 Ibidem: 26, 47.

${ }^{13}$ Lane, 1998: 18. Universidad de Sevilla, 2015.
} 
While designated fleet ports-o-call such as Havana, Veracruz, and Cartagena boomed, other ports and regions like Santiago and eastern Cuba suffered commercial isolation, forcing their residents to go without essential goods or pay higher prices because of the added expense of inland transportation. Not coincidentally, settlers in Jamaica, Hispaniola's northern and western coasts, and Puerto Rico's south were prone to engage in smuggling activities, importing European manufactured products such as tools and textiles in exchange for precious woods, ginger, tobacco, hides and other agricultural products. Smuggling activities also threatened Spain's Catholic exclusivism, as Protestant traders brought their bibles, religious tracts and practices. This notwithstanding, plenty of clergymen, included prelates, participated in smuggling activities. ${ }^{14}$

Following a brief truce in Franco-Spanish hostilities, both countries clashed again in 1552. The following year, the notorious Huguenot corsairs Francois Le Clerc (Peg-Leg) and Jacques de Sores attacked Havana, which, precisely that year, had been officially designated the island's most important city. Later, they raided the de jure capital city of Santiago, where they caused severe damage from which the city did not recover. These attacks marked the beginning of a new era of more militarized, violent, and cruel piratical attacks; corsairs became better trained and attacked with larger numbers of men, vessels, and artillery pieces. At times, they commanded actual French war ships.

The most devastating and best-documented attack of the period took place in 1555, when 200 men commanded by Jacques de Sores sieged and captured Havana's woefully vulnerable Fuerza Vieja. They took hostage its commander, Juan de Lobera, and some civilians who had found refuge there. Sores demanded 30,000 pesos and a substantial amount of cassava bread to feed his crews. The island's governor, Gonzalo Pérez de Angulo, had retrenched to the nearby Indian reducción of Guanabacoa, where he assembled a ragtag militia made up of around 35 Spaniards, 80 Indians and 220 blacks. ${ }^{15}$ When the Spaniards refused to pay the ransom, Sores hung several captives, a number of blacks among them. Before departing, his men raided and scorched the city. Virtually nothing remained standing; Havana was flattened, reduced to a smoking ghost town. Good iconoclasts that they were, Sores' men desecrated churches and removed vestments from images of virgins and saints, which they wore mockingly as hoods. Whether Spain and France were at war or not, corsair attacks continued; nine were registered between 1556 and $1566 .{ }^{16}$

${ }^{14}$ Newquist, 2011: 87-103.

${ }^{15}$ De la Fuente, 2008: 2. Wright, 1916: 239.

${ }^{16}$ Guerra y Sánchez, Pérez Cabrera, Remos y Rubio, and Santovenia y Echaide, 1952, vol. 1: 159-161 y 167. Wright, 1916: 241. 
Once again, Spain responded reactively and defensively by deploying a career military officer to govern Cuba and entrusting him with reinforcing Havana's fortifications. Captain-General Diego de Mazariegos arrived in 1556. He immediately imposed military rule and began preparations to build a new and stronger fortification that would also serve as the official residence of future captains general.

Mazariegos' return to Spain in 1565 was dramatic. His sworn enemies seized the vessel in which he traveled, took him hostage and demanded a ransom. Spanish naval forces soon freed Mazariegos and apprehended his captors, who were sentenced to forced labor in Havana's military constructions. It was common to punish captured enemies with hard labor at quarries and in grueling construction work. Black slaves, some of them confiscated by government officials, were also forced to work on military construction. In fact, all free blacks and mulattos were conscripted into that backbreaking work, with the threat of heavy fines or 100 lashes if they refused to do so. Guanabacoa's remaining Indians were compelled to carry out that harsh labor as well. ${ }^{17}$ When completed, the new fort, la Real Fuerza, was a magnificent Renaissance-style stone and mortar structure with four heavily fortified pointed bastions protruding out of its four corners. It was protected by ten-foot-wide walls, surrounded by a moat.

La Real Fuerza and future military constructions, armaments, ammunition, supplies, and salaries for officers and troops -estimated to number 450 regular soldiers by the century's end- required a continuous and massive influx of funds. Because Cuba was unable to meet those expenses, funds came from other locations in the circum-Caribbean, the rationale being that Havana protected the fleets and therefore must receive financial support from the jurisdictions that benefited from those fleets. There is documentary evidence of monetary transfers from Mexico to Havana going back to the early $1560 \mathrm{~s}$. These transfers were codified and institutionalized in the early $1580 \mathrm{~s}$, when the Crown ordered Mexico and other jurisdictions to send regular situados, established amounts of silver coins, to pay for military expenses Havana and other port cities incurred. Situado transfers became the economic lifeline of Cuba, Puerto Rico, Santo Domingo, and Florida. Havana alone received a yearly influx of 700,000 silver reales. Often, situados came late or failed to arrive because of shipwrecks or corsair attacks. When this happened, the region's fortified port cities became temporarily insolvent. ${ }^{18}$

\footnotetext{
${ }^{17}$ García del Pino, 2001: 39. Wright, 1927, vol. 1: 40. Sainz, 1972: 111.

18 De la Fuente, García del Pino and Iglesias Delgado, 1996: 102-103. Wright, 1927, vol. 1: 134 y $236-237$.
} 
“Papists" vs. "Heretics": Wars of Religion on Land and at Sea (1559-1603)

The Catholic Church and the papacy had remained virtually unchallenged for centuries until the first decade of the fifteenth century, when Catholic priest John Huss led a reformist movement in Bohemia. The movement continued after Huss' martyrdom but remained contained within the confines of Bohemia. Martin Luther, who the pope excommunicated in 1521, posed a greater challenge. Lutheranism found support in several German principalities and city-states that were part of the Holy Roman Empire. Parallel reformist movements emerged in Switzerland, France, and the Netherlands and later in Scotland. Reformism also took hold in England but in a different way with different results.

While Frenchmen and Spaniards fought one another in Europe and the Caribbean, England sided with Spain, largely because of dynastic alliances. In 1509, Prince Henry of England married Princess Catherine of Aragon and soon thereafter they were crowned king and queen. It was a tortuous marriage, to say the least, and Henry VIII began to separate from Catherine in 1527. When Pope Clement VII refused to annul the marriage, Henry VIII pushed the English Catholic Church to separate from Rome and become the Church of England, free from the pope's authority.

Following Henry VIII's death in 1547, yet another Anglo-Spanish dynastic marriage was arranged, this time between Spain's Prince Phillip and Queen Mary I, the Catholic daughter of Anglican Henry VIII. During their brief reign, the Church of England was again subject to the pope's authority. When Mary I died in 1558, Phillip II ceased to be king of England and England broke from Rome again. Her successor, Elizabeth, actually rejected a plan to continue the Anglo-Spanish dynastic union when she refused to consider marrying Philip; she was to remain virgin and Protestant.

As Protestantism spread further in European kingdoms such as England and France and it became predominant in other formerly Catholic nations, religious antagonisms played an increasingly important role in determining war and peace among the nations of Europe. Tensions increased between England and Spain, particularly following the ascent of Anglican Queen Elizabeth to the throne in 1558. The new English monarch's anti-Catholic zeal mirrored Philip II's trenchant hatred of the Protestant faith. Protestantism also spread in France and throughout parts of the Holy Roman Empire. By the mid-1560s, two discernible opposing blocs had taken shape: a southern European Catholic bloc led by Spain and a northern European bloc led by England.

One of the most valuable ideological weapons of the Reformation and wars against Catholic Spain was the "Black Legend," the systematic denigra- 
tion of Spain and its people, culture, and religion. Largely fed by the works of Bartolomé de las Casas, English and Dutch Protestants portrayed Spaniards as backward, dishonest, fanatical, cruel, and lazy. Dutch, English, and German editions of las Casas' Brief Account of the Destruction of the Indies circulated throughout Europe beginning in 1578 with titles such as "Spanish cruelties and tyrannies." Theodore De Bry, a Protestant, edited, illustrated, and published editions of las Casas' book and others on related topics and included gruesome engravings depicting Spanish cruelty. ${ }^{19}$

Nations that comprised these blocs were not free of internal religious tensions, however. Ongoing Catholic-Protestant enmity produced major uprisings and civil wars, most notably in France, the Netherlands, Ireland, and Scotland. While officially Catholic, France had a substantial minority of Huguenots, Protestants of Calvinist persuasion. Throughout most of the second half of the century, the French Crown focused its military resources on domestic wars of religion, fighting to eradicate Protestantism with varying levels of resolve and success. Huguenots were martyred by the tens of thousands and thousands more fled, settling in England, the Netherlands, and the Americas. Not a few became corsairs. These successive wars of religion lasted until 1598, when King Henry IV issued the Edict of Nantes, a declaration granting religious rights to French Protestants. Similar rifts divided the Netherlands into northern Protestant provinces and southern Catholic provinces.

Spain's relations with England further soured upon the crowning of Elizabeth in 1558. She openly supported the Dutch insurrection and aided Huguenot forces in France. After decades of increasing tensions and confrontations in the northern Atlantic and the Caribbean, Anglo-Spanish hostilities broke out in 1585, when the English Crown dispatched over 7,000 troops to the Netherlands and Queen Elizabeth liberally granted licenses for privateers to carry out piracy against Spain's Caribbean possessions and vessels. ${ }^{20} \mathrm{Ten}-$ sions further intensified in 1587, when Elizabeth I ordered the execution of Catholic Mary Queen of Scotts after twenty years of captivity and gave the order for a preemptive attack against the Spanish Armada stationed in Cadiz. In retaliation, Spain organized the famous naval attack that ended tragically for Spain with the destruction of the "invincible" Armada in 1588. Spain rebuilt its naval forces, largely with galleons built in Havana, and continued to

19 Early editions published outside Spain included Den Spiegel der spaensche tierannije (Dutch, 1578), Tyrannies et cruautés des Espagnols (French, 1579), The Spanish Colonie (English, 1583) and Narratio Regionum Indicarurum Per Hispanos quosdam devastatarum verissima (Latin, 1598). See Chartier, 2013.

${ }^{20}$ Parker, 1970: 89. 
fight England until Elizabeth's death in 1603. Spain, however, had received a near-fatal blow that ended its standing as Europe's most powerful nation and virtually undisputed master of the Indies.

Lacking Elizabeth's anti-Catholic fervor, her successor, James I, exhibited tolerance for Catholics. One of his first major actions was ending the prolonged and draining conflict with Spain: a year into his rule, he signed the Treaty of London, which dictated the withdrawal of English troops from the Netherlands in exchange for the removal of Spanish troops from Ireland and Spain's agreement to give up plans to restore Catholicism in England and Scotland. This turned out to be a lasting peace, which ended in 1624, shortly before his death. James I had consolidated power beyond England, retaining his Scottish crown and extending his rule to Catholic Ireland. In England, however, he earned the distrust of Puritans, who called for the elimination of Roman Catholic dogmas and practices from the official Church. These intraProtestant tensions continued to plague England for decades to come.

During Queen Elizabeth's reign, Franco-Spanish relations had been mostly peaceful and collaborative, largely because of their shared hostility toward the English monarch's militant and expansionist Protestantism. Spain helped the French Crown during its internal Wars of Religion. Religious strife flared up again in 1589, when King Henry IV of Navarre, a Catholic-baptized Protestant, became France's de jure monarch. Spain intervened in support of Catholic pretenders. To thwart King Henry's efforts to gain control of Paris, Spain deployed troops in 1590 and 1592. Henry's conversion to Catholicism in 1593, however, facilitated his de facto ascent to the throne in 1594. In 1595, he declared war on Spain, a conflagration that ended in 1598.

The Netherlands, which had been part of the Holy Roman Empire, came under direct control of the Spanish crown in 1555. Under Phillip II, the region endured tyranny manifested through increased taxation and violence against Protestants, whose numbers were rapidly growing, particularly in the north. Calvinist Protestantism became the dominant religion there by the $1560 \mathrm{~s}$, and in 1566 Protestants revolted against Spanish oppression. Early in the conflict, three southern, predominantly Catholic provinces seceded from the Seventeen Provinces and accepted Spanish rule, while the remaining United Provinces continued fighting for their political and religious independence, establishing a republican state in 1581. Spain, which had cemented a dynastic alliance with Portugal the previous year, responded with a heavy hand, dispatching a large army under the command of the infamous Duke of Alva.

The year 1568 marked the beginning of the Eighty Years' War, a war intertwined with other European conflagrations, with French, English, and German Protestants intervening on the Dutch side and the French Crown in- 
termittently supporting Spain. In 1596, both France and England recognized Dutch independence but Spain did not, so the war continued for another half-century, ending in 1648 when Spain finally accepted Dutch and Swiss Protestant independence.

The polarization of Europe along religious and geographic lines also played out in the Caribbean. Following the Franco-Spanish peace treaty of 1559, crown-sanctioned French corsair activities subsided, but piratical Huguenot incursions persisted and in at least one instance led to the formation of a temporary Huguenot settlement in the Isle of Pines, off Cuba. ${ }^{21}$ English piracy increased during the reign of Charles I, King of England, Scotland, and Ireland (1625-1649) and became more aggressive as Anglo-Spanish relations tensed up further during the Thirty Years' War. Although Spain and the Netherlands had been at war since the 1560 s, the Dutch were latecomers, appearing in the region only after the mid-1590s, when the Dutch Republic was no longer on the defensive in its long conflict against Spain. Dutch privateering became more widespread and violent beginning in the 1620 s.

While the French monarchy brutally repressed Huguenots at home, it had less power and less interest in doing so beyond the line. The Catholic Crown actually sanctioned Protestant corsair activities. In 1562, Huguenots established a foothold in Spanish Florida, where they built Fort Caroline. Fearing the spread of French and Protestant influence, Spain dispatched a sizeable armed expedition consisting of eleven vessels and around 2,000 men commanded by Fleet Admiral Pedro Menéndez de Avilés; he founded St. Augustine in 1565 and ordered his troops to march against Fort Caroline, where they quickly exterminated the French. Menéndez de Avilés then served as Cuba's captain general from 1567 to 1574 . He reinforced the island's defenses and aggressively pursued corsair vessels in the region. This marked a change in Spanish military strategies from defensive to increasingly offensive modes.

While the new fortification of Havana successfully deterred corsair attacks, the island's towns and cities in the interior remained vulnerable, becoming the preferred targets of corsair and pirate raids and smuggling expeditions. French pirates carried out numerous attacks on Santiago and other central and eastern locations. In 1578 they erased from the map -quite literally- the town of La Zavana, on the northern coast. Trinidad was terrorized into depopulation and other settlements had to be moved to safer locations in the hinterland. That is why Puerto Príncipe (Camagüey) is not on the coast, as its early name suggests, but forty-two miles inland.

\footnotetext{
${ }^{21}$ Morales-Carrión, 1974: 16.
} 
The most notorious and best-documented corsair offensive of the period was the 1603 attack on Santiago. Huguenot corsair forces under the leadership of Gilbert Girón burned and sacked the city, taking twenty hostages, most famously Bishop Juan de las Cabezas Altamirano. The prelate later reminisced about the abuses he suffered: "They took me in shirt sleeves and beat me repeatedly, they broke my leg with a musket." The hostages remained captive in a corsair vessel for eight days while Girón waited for the ransom to be collected. Local residents managed to lure Girón inland, where they ambushed him. The lance of Salvador Golomón, a free black man, pierced Girón's body. The corsair's head was later cut off and paraded all the way to the town of Bayamo, where reportedly adults and children alike cheered effusively. ${ }^{22}$

English incursions in the Spanish-claimed Caribbean boomed during Queen Elizabeth's rule. These actions originally took the guise of well-organized, large-scale smuggling expeditions headed by piratical smugglers the likes of John Hawkins, John Oxenham, and Francis Drake; their primary objectives were smuggling African slaves into Spain's Caribbean possessions in exchange for tropical products. The first instances of English mercantile piracy took place in 1562-63, when Hawkins' men raided a Portuguese vessel off the coast of Sierra Leone, captured the 300 slaves on board, and smuggled them into Santo Domingo in exchange for sugar, hides, and precious woods.

Hawkins and his contemporaries mastered the devilish art of maximizing the number of slaves that could fit into a ship. He and other slave traders methodically packed slaves by having them lay on their sides, spooned against one another. Such was the case of the slave-trading vessel bearing the sublime name Jesus of Lübeck, into whose pestilent bowels, in partnership with Elizabeth I, Hawkins jammed 400 African slaves. ${ }^{23}$

In 1567 and 1568, Hawkins commanded two piratical smuggling expeditions, the last of which ended disastrously; he lost almost all of his ships and three-fourths of his men were killed by Spanish soldiers at San Juan de Ulúa, off the coast of Veracruz, the point of departure of the fleet of New Spain. Hawkins and Drake barely escaped but Oxenham was captured, convicted of heresy by the Inquisition and burned alive.

Many of the battles of the Anglo-Spanish war of 1585-1603 were fought in the Caribbean, not by regular English troops but rather by privateers whom Queen Elizabeth had licensed to carry out attacks on Spanish vessels and ports. These were former pirates who now held a more venerable status as privateers. During those years, over seventy-five documented English priva-

${ }^{22}$ Cruz-Taura, 2009: 224.

${ }^{23}$ Lane, 1998: 35. 
teering expeditions targeted Spanish possessions and vessels. Drake terrorized Spanish vessels and ports. Early in 1586, his forces seized Santo Domingo, retaining control over it for around a month. Before departing they plundered and destroyed the city, taking a huge bounty. Drake's men destroyed church images and ornaments and even erected a defensive palisade with wooden images of saints in the hope that the Spanish soldiers' Catholic fervor would keep them from firing- saints as human shields of sorts. ${ }^{24}$

Drake and his men proceeded to attack the port city of Cartagena, later landing on Cabo Antonio (Cuba's westernmost point) to water their vessels. The sight of Drake's convoy spread terror among habaneros, who in preparation for the anticipated attack, called for and received reinforcements from Mexico and installed a cedar-and-metal chain that stretched from one side of the bay's mouth to the other, a nautical chastity belt of sorts. While the attack never materialized, El Drake became the region's boogeyman: the mere mention of his name continued to inspire fear long after his death.

Two years after Drake's campaign and the destruction of the Spanish Armada, Spain shifted its strategy, increasingly funneling its resources toward the erection of new and stronger fortification throughout the circum-Caribbean. In Havana, beginning in 1587, Field Marshal Juan de Tejada and engineer Giovanni Battista Antonelli directed the construction of two new forts, one at each end of the entrance of the bay: El Morro to the east and the smaller La Punta fortress on the west. By 1607, El Morro had a functioning battery of twelve cannons that were named after the twelve apostles. Both fortifications were completed in 1630 .

The flow of transatlantic vessels convoyed into fleets rose dramatically during the peak years of Mexican silver production from the 1580s to 1610s. All of them passed through Havana, where they anchored inside its bay for weeks or months at a time. Five hundred forty-one registered fleet vessels passed through Havana between 1585 and 1600, but the actual number of vessels was much higher. ${ }^{25}$ This translated into economic prosperity for Havana and its hinterland, as fleets had to be serviced and repaired, and crews required food, liquor, lodging, entertainment, and other goods and services. The passing and prolonged stays of fleets and vessels involved in regional and intercolonial trade made Havana and the waters near it the primary target of pirates and privateers.

When Spain imposed a trade embargo on the rebellious Dutch provinces, depriving them of access to salt and goods that had been previously supplied

\footnotetext{
${ }^{24}$ Morales-Carrión, 1974: 19, note 38.

${ }^{25}$ De la Fuente, 2008: 13.
} 
by Portuguese merchants, it pushed them into smuggling and piracy. Dutch smugglers were particularly interested in the prodigiously rich salt deposits of Punta Araya (in present-day Venezuela), the pearl fisheries of La Margarita, as well as treasures carried by Spanish fleets. The level of Dutch smuggling and piracy was such that between 1599 and 1605 over 760 Dutch vessels sailed to Punta Araya, alone. In January 1606, off the southeastern coast of Cuba, Spanish vessels under Admiral Juan Álvarez de Avilés successfully fought thirty-one smuggler vessels, twenty-four of which carried the tricolor ensign of the Dutch Republic. ${ }^{26}$ Following the Dutch-Spanish truce of 1609, these violent incursions came to a halt when Dutch privateers shifted their attention to South America.

Dutch Corsairs, English Settlers, and Stateless Buccaneers (1604-1648)

There was not a single year of peace in Europe during the first half of the seventeenth century. This was especially true for Spain, which began the century at war with the Dutch and subsequently went to war against almost every other European nation. The Spanish Crown and its Portuguese ally became embroiled in the continent's major conflicts, most of which were intertwined with their ongoing Eighty Years' War against the Netherlands (1568-1648). The Thirty Years' War (1618-1648) overlapped with the last fifty years of the Eighty Years' War. This conflagration began and was mostly fought in Central Europe, namely in German states and in Bohemia, where persecution of Protestants sparked a revolt in 1618. As other nations joined the war (England in 1624, France in 1635, and Portugal in 1641), it became a conflict between Spain and the Hapsburg Empire against virtually the rest of Europe. Both the Thirty and Eighty Years' Wars ended with a series of treaties known as the Peace of Westphalia in 1648.

While these wars usually pitted Protestant and Catholic nations against one another, on occasion Catholics fought Catholics and Protestants went to battle against fellow Protestants. Religion was no longer the driving ideological weapon it had been in the previous century. The 1600s were characterized by cross-faith alliances, dynastic marriages between Catholic and Protestant royals, and greater religious tolerance within the European nations, Spain excepted.

Religious unity, however, had not been fully established within contending nations, with the exception of Spain and Portugal. In France, Catholics and

${ }^{26}$ Butel, 1999: 90. Moreno-Fraginals, 1995: 73. 
Huguenots tensely coexisted under the protections afforded to Protestants by the Edict of Nantes, but Huguenot revolts persisted, as did Catholic attacks against Protestant strongholds. England, for its part, continued to be torn by conflicts between Catholic-sympathizing monarchs with pro-French inclinations and a Parliament that was strongly influenced by Puritanism and sought to increase its power vis-à-vis that of the Crown.

Religious factors were even less important in the Caribbean. There was only a small number of clerics in Cuba and the rest of the Hispanic Caribbean and a miniscule presence of Anglican priests and Protestant pastors in the emerging English colonies. England and Spain were no longer ruled by religious zealots the likes of Queen Elizabeth and Philip II. The Dutch, meanwhile, were the most tolerant. In the Caribbean, money was their god and privateering expeditions their crusades. In the continent, they welcomed religious dissenters from everywhere: French Huguenots, Bohemian Protestants, and Jews from throughout Europe. In the Caribbean, they shared islands, coexisted with Catholic settlers, and fought against Protestant settlers when they had to. A Calvinist work ethic, thriftiness, and the practice of religious tolerance were, in fact, primary factors behind Dutch success in global trade; they borrowed from Jews and traded with Catholics, Protestants, pagans, and seemingly godless pirates and buccaneers. Another characteristic that set them apart was their belief in free trade, in contrast to the other naval powers that insisted on exclusivist trade practices.

The twelve-year truce between Spain and the Dutch Republic of the Seven United Netherlands expired in 1621 and war reignited. Significantly, in that same year, the republic chartered the Dutch West India Company, giving it a monopoly over trade and navigation in the Americas and the profitable transatlantic slave trade. The Dutch smuggled European manufactures such as textiles, tools, weapons, forbidden books, and slaves. They were mostly interested in purchasing or plundering salt, sugar, dyes, tobacco, and precious woods. They also traded with French and English settlers, regardless of whether they were at war with their nations or not. At their peak, the Netherlands surpassed the English in trade and navigation volume and earned naval superiority in the Atlantic and the Caribbean.

During the 1620s and 1630s, when the chartered Dutch West India Company began operations, Dutch privateering peaked. Pirates and privateers were becoming businessmen of sorts. The company served not only commercial purposes but also military functions. Altogether, during those two decades, there were nine foreign attacks on Cuba and naval actions in Cuban waters. ${ }^{27}$

\footnotetext{
${ }^{27}$ García del Pino, 2001: xi. Marley, 2008: 106-127.
} 
A Dutch vessel captured a Spanish merchant ship off Cuba's western tip in 1624. The following year, a Dutch fleet commanded by Boudewijin Hendrickzs staged a major attack against San Juan. They left five weeks later, but not before looting and destroying the city. In 1626, Hendrickzs' fleet blockaded Havana with the intention of capturing the next Spanish fleet. The following three years witnessed an unremitting campaign against Spanish ships and intermittent blockades of the Bay of Havana. In 1628, Vice Admiral Piet Heyn of the Dutch West India Company launched the most successful and profitable attack ever against the Spanish fleet as it headed back to Europe. Commanding 32 vessels with 700 cannon, Heyn captured the treasure-laden fleet after it passed Havana. The Spanish fleet's commander, Juan de Benavides, ordered his remaining vessels to seek refuge in the Bay of Matanzas, where Heyn's men captured the fleet in its entirety. The bounty was prodigious: 178,000 pounds of silver, 125 pounds of gold, pearls, indigo, cochineal, hides, sugar, and spices. All told the bounty, amounted to 4 million pesos, a 50 percent return for the company's shareholders. ${ }^{28}$

Dutch privateer vessels continued to harass vessels sailing near Havana over the next decade. They failed in an attempt to capture Havana in 1629, raided Santiago in 1635, and continued to sail off the coast of Havana with the intention of raiding fleets and loose vessels. Spain's treasure fleets were routinely forced to delay their departures and change routes in order to avoid capture. In 1638, yet another peg-legged privateer, Cornelius Jol, menaced Havana with a 20 -ship fleet for over a month. He captured two Spanish vessels. Two years later, another formidable Dutch squadron appeared near Havana with the intention of raiding the Spanish fleet. A storm dispersed the privateer vessels, destroying some of them; the bad weather saved the Spanish fleet. ${ }^{29}$

Notably, Jol's second in command was a Cuban mulatto runaway slave. Named Diego Martín, this seafaring maroon led a life of piracy, rose to the rank of ship captain, and married a Dutch woman. He was not alone. Other blacks and mulattos joined pirate and privateer vessels as places of freedom, refuge, and source of fortune. Spanish authorities and colonial settlers feared enslaved and free blacks and mulattos, whom they viewed as natural allies of pirates and privateers. ${ }^{30}$ After two decades of intense Dutch piracy in the region and continuing war between Spain and the Dutch Republic, not a single recorded corsair or pirate attack from any nation took place in and around Cuba between March 1641 and 1651. Spain was on the offensive, launching

\footnotetext{
28 Williams, 1970: 84.

${ }^{29}$ Wright, 1921: 628.

${ }^{30}$ García del Pino, 2001: 31.
} 
numerous attacks to destroy foreign settlements in the region of the Larger Antilles and its periphery. ${ }^{31}$

Meanwhile in England, shortly before assuming the Crown, Charles I married French princess Henrietta Maria, the Catholic sister of the King of France. This dynastic alliance included secret negotiations, among them a promise that England would support France militarily in its efforts to wipe out the Huguenots. This alliance with Catholic France gave credence to denunciations of Francophilia that Puritan members of Parliament launched against Charles I. He reneged on his prenuptial promise and reversed his position, sending English troops to fight on the side of the Huguenots instead. He also escalated the war against Spain, but England lost every major battle and failed to gain any new territories.

A trenchant believer in the divine right of absolute monarchical rule, Charles I reduced civil liberties and imposed new onerous taxes to pay for the war against Spain and other conflicts. He ruled tyrannically and treated Puritans with contempt; this was also the case in Scotland against Presbyterian Covenanters and in Ireland against Catholics. Increasing religious tensions led to the War of the Three Kingdoms, which included revolts and civil wars in England, Scotland, and Ireland. Irish Catholics revolted in 1641; the following year, English Puritans led by Parliament started the first of three civil wars against royalist forces. In Scotland, Presbyterian Covenanters revolted against Charles I in 1644.

During the Anglo-Spanish war of 1624-1630 and for decades to come, English and French settlers managed to establish permanent foreign settlements in Spain's mare clausum. The year 1624 was a major milestone in the history of the Caribbean. That year, British settlers led by Thomas Warner, who had a license but no formal support from the English Crown, founded a colony on the Island of St. Christopher (St. Kitts). It was one of numerous smaller islands that Spain claimed but did not occupy. St. Christopher proved valuable for the expansion of English colonialism. Settlement expeditions to Nevis, Antigua, Montserrat, and Tortuga departed from St. Christopher.

The island also had the distinction of hosting the region's first French colony, as English settlers welcomed their French counterparts who arrived in 1625. St. Christopher was now shared among the English, French, and native Caribs, who opposed the colonizers and sided with Spain. The island was formally partitioned; an English band of territory was sandwiched between the northern and southern French bands. A French corporation, La Compagnie de Saint-Christophe, administered French St. Christopher and future French

\footnotetext{
31 Ibidem: xi. Marley, 2008: 198-209.
} 
colonies. Unlike the hands-off colonial approach of the English Crown, French royals and their close associates participated actively by investing in settlement projects, trade, and agricultural ventures. France also exercised greater political control over its new colonial domains. ${ }^{32}$

The type, extent, and purpose of foreign encroachments varied from island to island. Some, like Barbados, which the English colonized in 1627, were extensively settled by indentured servants and other white immigrants who produced non-edible export crops such as tobacco and cotton. ${ }^{33}$ Later, Barbados, followed by other English outposts, became a "colony of exploitation." Caribbean scholar Franklin W. Knight used that term to refer to islands that beginning in the 1640s developed monocrop economies based on slave labor and the sugar plantation model. He contrasted these "exploitation colonies" with "colonies of settlement," Cuba and Puerto Rico, for example, which, while producing some staple crops, had economies based on agriculture for the local market, using mostly free labor. ${ }^{34}$ As English and French planters and masters of indentured servants (engagés in French) became increasingly exploitative and cruel, many servants fled; some like François L'Olonnais, Alexandre Olivier Exquemelin, and Henry Morgan becoming prominent buccaneers in places like Tortuga and Jamaica. ${ }^{35}$

Knight's spectrum, while useful, does not fully represent two other types of early Caribbean settlements: places such as the north and west coasts of Hispaniola, Tortuga, and Île-À-Vache that were unstable, informal, lawless, and stateless buccaneer enclaves. They were bases for piratical aggression and providers of cooked meats, bread, and water for passing vessels. Yet another type of colonies consisted of lightly populated mercantile bases, islands the likes of Curaçao and Saba, which were first settled in the 1620s and 1630s by the Dutch West India Company to serve as bases for legal trade, smuggling, and raiding expeditions.

I propose expanding Knight's typology by adding two additional spectrums; one connected to the "settlement colonies" pole, with two poles of its own: (1) large-scale formal settlements like Havana and (2) buccaneer enclaves such as Tortuga. The other spectrum stems out of the other pole of Knight's original spectrum, "colonies of exploitation." Its new poles consisting of (1) full-fledged plantation societies like Guadeloupe and (2) small mercantile and privateering posts the likes of Curaçao and Sint Eustatius.

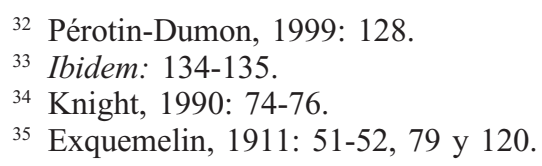




\section{Typology of Early Caribbean Colonies}

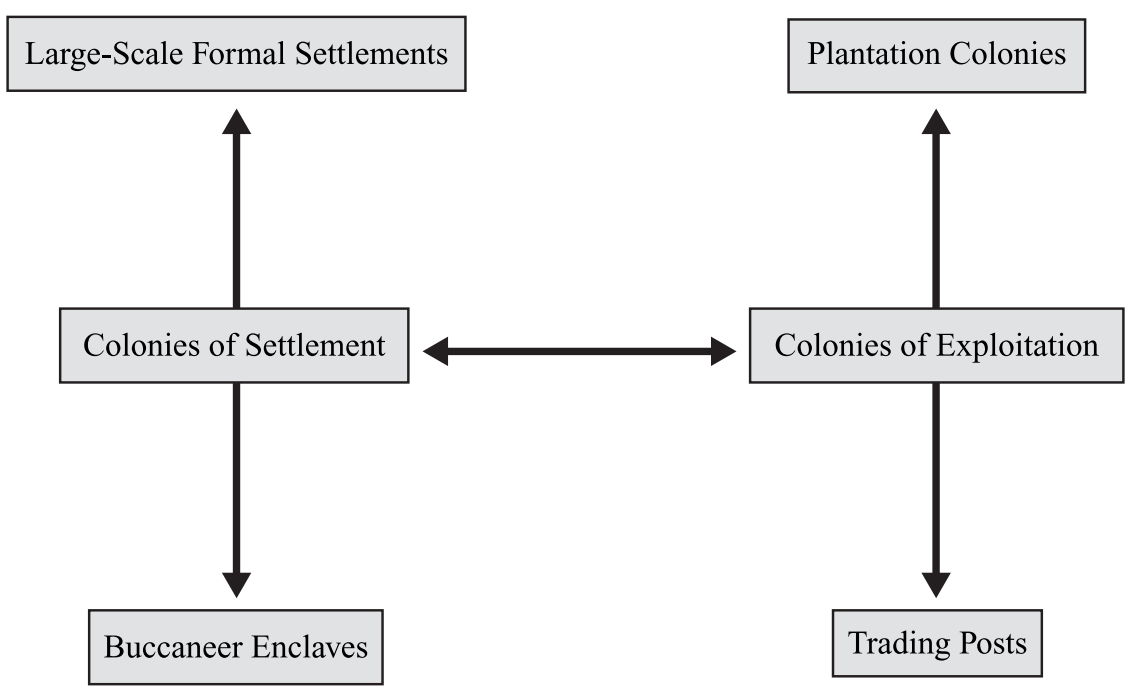

Large-scale formal settlement colonies, such as Cuba, were stable, had larger populations, were fortified, and had close relations with their respective metropolitan powers. At the other end of this new spectrum, buccaneer enclaves such as Île-À-Vache, were lightly populated, unstable, temporary, and had little or no connection with their respective European powers. Meanwhile, the other new spectrum ranged from intensely cultivated slave societies- Barbados stands out as the earliest example- and intensely commercial "colonies of exploitation," first and foremost, Curaçao.

Special geographic, demographic, and political circumstances made for a highly distinct colonial experience in Barbados, the first to become a colony of exploitation and the one that most resembled England in terms of political, legal, and church institutions. While considered a Caribbean island, Barbados is actually 170 kilometers off the arch of the Lesser Antilles, farther away from the epicenter of Spain's Caribbean. Unlike its neighboring islands, it did not have volcanic origins; it was formed as the result of millions of years of accumulation of sediment from the Orinoco Basin. Its location and topography also made Barbados less insalubrious and therefore a more propitious environment for the survival of non-acclimated European settlers. Unlike other islands settled 
by the English and the French, it had no indigenous population with which to contend. Barbados was first populated mostly with English indentured servants employed by private companies. By the 1660 s, however, there were more black slaves than white settlers and 60 percent of the land was devoted to sugarcane. In 1660, it was deemed "the richest spot in the English New World Empire." 36

The other type of exploitation colonies included Sint Marteen, a salt-rich island first occupied by Dutch privateers in 1631. Spanish forces destroyed the settlement and actual permanent Dutch colonies did not materialize until years later with the recapture of Sint Marteen and the on-again, off-again possession of Aruba, Curaçao, Bonaire, Sint Eustatius, and Saba. Although these islands developed agriculture and mining, they were strategically located, well-defended entrepôts whose primary function was to serve as bases of illegal and legal trade. The Dutch West India Company owned and administered these colonies, and selected their governors. ${ }^{37}$

Havana, San Juan, and Santo Domingo were settler colonies par excellence. They were also at one pole of my proposed spectrum ranging from large-scale formal colonies and emerging buccaneer enclaves. Tortuga was a buccaneer post with tortuous and violent beginnings. It was strategically located in the Windward Passage between Cuba and Santo Domingo. Spaniards first settled Tortuga, precariously so, in 1625, over 130 years after Spain first claimed it. The timing had more to do with preempting a foreign takeover than a desire to turn it into a useful island. While inhabited by buccaneers since the mid1620 s, English colonial sovereignty over Tortuga was slightly formalized only in 1631, when the Providence Company appointed Captain Anthony Hilton as governor. In light of repeated successful attempts by Spanish forces to depopulate Tortuga, the Company's presence was weak and fleeting. In 1634, French authorities transferred the renamed Crown-subsidized Compagnie des Îles de l'Amérique to Tortuga, from where privateer expeditions were launched to wrest the large Windward Islands of Martinique and Guadeloupe, shortly upon the start of the Anglo-French War in 1635. In 1638, English adventurers from St. Christopher, reoccupied Tortuga but shortly thereafter, the French reassumed control. Over the next three decades, Tortuga exchanged hands more times than any other Caribbean possession, seesawing between Spain and the buccaneers, between French and English colonists, and between privateers and buccaneers. Tortuga was a multinational enclave of French, English, Dutch, and Portuguese settlers. ${ }^{38}$

\footnotetext{
${ }^{36}$ Koot, 2011: 55. Beckles, 1990: xiii.

37 Pérotin-Dumon, 1999: 129.

${ }^{38}$ Haring, 1910, 57-83.
} 
Spain responded to piratical aggression, widespread contraband, and privateer expansionism with a combination of defensive and offensive measures. Early in the century, it systematically depopulated the northern and western coasts of Hispaniola to keep inhabitants from trading with French and English buccaneers. Spanish officials carried out similar devastaciones in the Wild Coast of South America to keep Dutch privateers from extracting salt and trading spices, tobacco, and other goods with indigenous people. The devastaciones, however, backfired. In the case of Santo Domingo (1605-1606), once Dominican settlers were violently removed from port towns such as Montecristi and Puerto Plata, French and English buccaneers from Tortuga moved in to hunt cattle and pigs and harvest cotton, tobacco and other products they had previously purchased from local Spanish residents. ${ }^{39}$

With similar objectives, the Spanish Crown prohibited the production of tobacco in Cuba and elsewhere because that crop was among the most soughtafter contraband commodities. Spain also further fortified its ports throughout the Caribbean. In the period 1636 to 1643, Cuban slaves, captured corsairs, and other coerced workers erected the twin fortifications of La Chorrera west of Havana and Cojimar to the east. Construction on the most ambitious military works to date, El Morro, began at the same time. An expanded system of coastguard vessels helped curb contraband; while the fleet system became increasingly ineffective and therefore more vulnerable.

The Peace of Westphalia that ended the Eighty Years' and Thirty Years' Wars strengthened the principles of national sovereignty and the right of nations to decide on internal religious matters. A defeated Spain and Holy Roman Empire were forced to recognize Dutch, Bohemian, and Swiss independence. Spain also lost its dynastic alliance with Portugal, which declared its independence in 1640. Fighting continued between these former allies for nearly three decades. In the Caribbean, Spain had to recognize already established English, French, and Dutch colonies in exchange for pledges by Europe's naval powers to reduce piracy and privateering activities in the New World. Accordingly, because of its curtailed access to the Caribbean, the Dutch West India Company endured enormous losses and faced bankruptcy. Other nations' privateers and buccaneers flouted the peace of Westphalia and continued their violent attacks throughout the region.

\footnotetext{
${ }^{39}$ Gosse, 2007: 144. Scarano, 2011: 185.
} 
Protestant Republicans, Catholic Royalists, and Beyond-the-Line Colonials (1649-1670)

The twenty-odd years between 1648 and the Treaty of Madrid in 1670 demonstrated the limited success of the Peace of Westphalia. On the one hand, a defeated and bankrupt Spain, with much reduced influence in the Holy Roman Empire and Italian Peninsula, gave up its crusade to contain the spread of Protestantism in Europe and beyond. It also gave up on maintaining religious exclusivism in the Caribbean. Religion had been the primary dynamo behind Spain's belligerence for over a century but the containment of Protestantism was no longer enforceable on either side of the line, except in the colonies that it firmly controlled. On the other hand, the treaties of 1648 did not bring sustained peace to Europe, and wars for commercial control and territorial expansion continued to ravage the continent and the British Isles.

In a reversal of the pattern of the previous eight decades, Spain and the Dutch Republic ceased fighting against each other and even became allies against common enemies. With the exception of a few months in 1659-1660, Spanish and French troops battled each other from 1648 until the end of the century. These conflagrations further debilitated Spain both on land and at sea and allowed France to gain military hegemony on the continent. England and Spain were also at war until the end of Cromwell's Protectorate (1659). After a brief moment of peace following the ascent of Charles II in 1660, tensions resurfaced, culminating with renewed hostilities in 1665. Spain's other major adversary was Portugal. The two Iberian nations, which had been at war since 1640 , signed a peace treaty in 1668 , when Spain finally recognized its neighbor's independence.

These wars were intertwined with revolts in France, England, and Scotland that turned into civil wars, pitting religious minorities against absolutist monarchies. In response to the French monarchy's efforts to curtail the power of French courts of appeal (parlements) and raise taxes to pay for wars past, present, and future, French frondeurs rose up against royalist forces in 1648. A parallel insurrection exploded in England in 1649, when Charles II, King of England, Scotland, and Ireland, was captured and beheaded and parliamentarian forces under Oliver Cromwell established a commonwealth government that also included Scotland, Ireland, and Wales. In 1653, Cromwell dismantled the Parliament and established military rule under his protectorate. It lasted until shortly after Cromwell's death five years later. The victim of eye-for-eye justice, the Puritan lord protector was beheaded posthumously by royalist hands.

England's civil wars found a battlefield of sorts in Barbados, where government officials and the general population were split between royalists and 
parliamentarians. Because Barbados mostly sided with Charles II, the Commonwealth Parliament punished the island, first by banning it from trade with England and later by sending troops to bring royalists under submission. ${ }^{40}$

Parlamentarians, who had long called for a more aggressive Caribbean policy, launched the epic Western Design invasion in December 1654. Cromwell ordered General Robert Venables to land troops "upon any of the territories, dominions, and places belonging unto, or in the possession of the Spaniards in America, and to surprise their forts, take or beat down their castles and places of strength, and to pursue, kill, and destroy by all means whatsoever all those who shall oppose or resist you therein." The Western Design was by far the largest military action of its kind to date; it included over thirty-five vessels and nearly 10,000 soldiers, most of them recruited in Barbados and St. Christopher, including indentured servants the likes of Henry Morgan. ${ }^{41}$ General William Penn's fleet and Venables' soldiers failed in their task of capturing the primary target of Santo Domingo and proceeded toward the island of Jamaica, which was poorly defended and populated by only 1,500 inhabitants. Spaniards surrendered and retreated to Cuba; their slaves moved to remote locations where they built maroon communities.

Jamaica, the third largest of the Greater Antilles with an area twenty-five times larger than Barbados', became an invaluable English possession. Unlike Barbados, it was strategically located near the epicenter of Spanish colonialism, within striking distance of Cuba and Hispaniola. Its large size and mountainous topography made it a haven for stateless peoples, including black maroons and buccaneers. While Barbados had a substantial presence of English political, judicial, economic, and religious institutions, Jamaica evolved into an autonomous buccaneer enclave. In Jamaica, as elsewhere in the region, buccaneers lived and died beyond the line; they had their own informal institutions, their own rules about crime and punishment, and a fluid social structure based on egalitarian and democratic decision-making practices. ${ }^{42}$

That said, England and the buccaneers developed a symbiotic relation. In 1657, the English protectorate and Jamaica's buccaneers entered a formal alliance to keep Spain from recapturing the new English possession. This unholy alliance of pious Puritans and wicked buccaneers worked to consolidate a permanent English presence in Port Royal, soon to become a prosperous trade emporium rivaling Havana. For decades thereafter, buccaneers proved helpful to English mercantile and military ambitions, routinely launching at-

\footnotetext{
40 Dunn, 1973: 80. Marley, 2008: 145-147.

${ }^{41}$ Burchett, 1720: 387-388. Exquemelin, 1911: 120.

${ }^{42}$ Exquemelin, 1911: 59-60.
} 
tacks against Spanish possessions and vessels in the Antilles, and off Central America and northern South America. Jamaica also served the English navy as a launching pad for expeditions against Spanish and other targets. That was the case in 1656, when Vice-Admiral William Goodson led fifteen men-of-war to Cuban waters, where they blockaded Havana to capture treasure fleet vessels.

Buccaneering activities peaked during the second half of the seventeenth century, not only in Jamaica but also in other locations on or near the Windward Passage: Tortuga, the northern and western coasts of Hispaniola, and Île-À-Vache. Tortuga-based buccaneers staged numerous attacks on Spanish possession and vessels launching a major offensive on Hispaniola in 1659. That year the French and English governments jointly appointed Frenchman Jérémie Deschamps de Rausset governor, a reflection of the hybrid or frontier political nature of Tortuga. In 1662, England brought Tortuga under royal sovereignty, but it continued to be a haven for the English, French, and Dutch alike. Two years later, it reverted to French rule. ${ }^{43}$

In the 1660s, major changes altered Europe's political and geopolitical map, arguably more than the Peace of Westphalia had. In 1659, France and Spain signed a peace treaty. The following year, England saw the restoration of absolutist monarchical rule under Charles II, who, like his predecessors, was a Francophile and a Catholic sympathizer. These events led to a prolonged period of peace with Spain. Anglo-French hostilities also waned until the Second Anglo-Dutch War (1665-1667), in which France sided with the Netherlands. The War of Devolution (1667-1668), sparked by a French invasion of the Spanish Netherlands, became yet another multination war. France had just signed an alliance with Portugal, a country long at war with Spain. Spain, meanwhile, fought on the side of an alliance formed by the English and Swedish kingdoms and the Dutch Republic, which had ended its war against England in order to focus on fighting French expansionism. The War of Devolution resulted in minimal gains for France and the recognition of an independent Portugal.

The English restoration of 1660 was not welcomed in the English-speaking Caribbean, not even in the most English of the colonies. The Crown sought to tighten control over its Caribbean colonies. In Barbados it reduced the economic and political power of the planter elite, raised export taxes, and imposed harsher navigation acts, forbidding all of its colonies to trade with vessels not carrying the English flag. ${ }^{44}$

\footnotetext{
${ }^{43}$ Haring, 1910: 113-119. Exquemelin, 1911: 9-15.

${ }^{44}$ Dunn, 1973: 80.
} 
As was the case during the previous century and a half, European conflagrations reverberated beyond the line, and often Caribbean settlers, pirates, and soldiers engaged in conflicts that did not correlate with European events. Such was the case in 1662, when England and Spain were at peace and yet buccaneers from Jamaica launched ferocious attacks against Santiago de Cuba, Santo Domingo and beyond. Similar attacks continued during the rest of the decade. Governor Thomas Modyford chastised Jamaica's buccaneers for their continuing aggressions against Cuba and Hispaniola, such as the 1665 raid against the Cuban town of Sancti Spiritu. Following that attack, Modyford expelled the buccaneers from Jamaica; a costly decision, it turned out, because productivity, trade, and revenues plummeted. To lure them back to Jamaica, Modyford reluctantly granted licenses to carry out attacks against Spanish targets in the circum-Caribbean. One of the recipients was Edward Mansfield, who led attacks against various Spanish ports. ${ }^{45}$ Following his capture and execution by Spanish officials, Henry Morgan, at the time head of Port Royal's militia, became chief of the buccaneers. He launched a major attack against Puerto Príncipe in 1668. Morgan's warning to the inhabitants was eerily reminiscent of the sixteenth-century requerimiento proclamation that Spanish conquerors were supposed to read before attacking native villages. "If you do not surrender voluntarily," Morgan warned ominously, "you will see your town in flames and your women and children torn into pieces." 46 Morgan's men carried out unspeakable atrocities in Puerto Príncipe, including torturing captives and starving women and children to death.

During the Anglo-Dutch War, England's official position was to redirect its aggression against Dutch vessels and ports. Since England had no desire and lacked the resources to take over any more Spanish islands, it turned its energies against the Dutch who routinely undermined English commercial exclusivism. Modyford commissioned English buccaneers to attack Dutch interests. They raided Bonaire and Saba and captured St. Eustatius. Commanded by Abraham Crijssen, the Dutch retaliated, capturing Tobago and forcefully seeking to reclaim St. Eustatius. When the second Anglo-Dutch war ended in 1667, England ceded some trade privileges to the Dutch. Even when the Dutch and the English agreed to stop fighting, English and Dutch privateers continued to clash violently over possessions in the Guianas.

The French, meanwhile, attacked English and Spanish targets throughout the circum-Caribbean. In 1665, before France declared war on England, French privateers took control over all of St. Christopher and Antigua, Montserrat,

\footnotetext{
${ }^{45}$ Haring, 1910: 196-197.

46 Exquemelin, 1911: 143. Marrero, 1975, vol. 3: 140.
} 
Nevis, and Tortuga. French and Dutch fleets combined efforts to defeat English forces. The English, for their part, repeatedly attacked Guadeloupe, Martinique, and French-occupied St. Christopher, and Nevis.

As negotiations for peace among France, England, and the Netherlands ensued, in May 1667, France declared war on Spain and turned its attention to Spain's possessions. Tortuga-based French Calvinist buccaneer L'Olonnais organized an expedition against Havana but found it to be well defended by numerous warships; he landed elsewhere on the island where he unleashed his characteristic brutality. His ulterior plan was to attack Maracaibo and other mainland Spanish ports. Spain responded with a new strategy: licensing its own corsairs as its adversaries had been doing for a century and a half.

Even though England and Spain were at peace and in 1670 signed the Treaty of Madrid, which outlawed further buccaneering activities in the Caribbean in return for Spain's promise of not seeking to retake islands under English control, Jamaica's buccaneers insisted on assaulting Spanish ports in Cuba and elsewhere. Buccaneer raids were Jamaica's economic lifeline, and, concerned about a buccaneer insurrection and aware of the role they could play defending the island from Spain, Modyford had no option but to turn a blind eye.

Morgan's men continued to launch unauthorized piratical actions even after English authorities took control of Jamaica from the buccaneers. In response to yet another unauthorized piratical attack, British authorities arrested Morgan in 1672. While he was in custody on the other side of the line, the Crown tried to rehabilitate Morgan, knighting him and appointing him official governor of Jamaica. Appointments and knightings notwithstanding, English, Spanish, Dutch, French and settlers, merchants, and soldiers continued to lead lives beyond the proverbial line in Europe's cockpit.

\section{BIBLIOGRAPHY}

Beckles, Hilary, A History of Barbados: From Amerindian Settlement to Nation-State, New York, Oxford University Press, 1990.

Brevoort, James Carson, Verrazano the Navigator; or Notes on Giovanni da Verrazano and on a Planisphere of 1529 Illustrating his American Voyage in 1524, New York, American Geographic Society of New York, 1874.

Burchett, Josiah, A Complete History of the Most Remarkable Transactions at Sea,

London, W. B., 1720. 
Butel, Paul, The Atlantic, London, Routledge, 1999.

Chartier, Roger, "Materiality and Mobility of a Text: Bartolomé de Las Casas'<Brevíssima Relación de la Destruycion de las Indias> between Sevilla, Antwerp and London", paper presented at Columbia University, February 25, 2013. Note in http://medren.columbia.edu/events/materiality-and-mobility-of-a-text-bartolomede-las-casas-brevissima-relacion-de-la-destruycion-de-las-indias-between-sevillaantwerp-and-london/ (Accessed February 10, 2015).

Cruz-Taura, Graciella, Espejo de Paciencia y Silvestre de Balboa en la historia de Cuba, Madrid, Iberoamericana, 2009.

De Balboa, Silvestre, Espejo de paciencia, Miami, Ediciones Universal, 1970.

De Espronceda, José, Antología poética, Madrid, Ediciones Akal, 1999.

De la Fuente, Alejandro, Havana and the Atlantic in the Sixteenth Century, Chapel Hill, University of North Carolina Press, 2008.

De la Fuente, Alejandro; García del Pino, César and Iglesias Delgado, Bernardo, "Havana and the Fleet System: Trade and Growth in the Periphery of the Spanish Empire, 1550-1610", Colonial Latin American Review V/1 (Albuquerque, New Mexico, 1996): 95-115.

Dunn, Richard, Sugar and Slaves: The Rise of the Planter Class in the English West Indies, 1624-1713, New York, Norton, 1973.

Exquemelin, John [Alexander Olivier], The Buccaneers of America, London, George Allen \& Co., 1911.

García del Pino, César, El corso en Cuba. Siglo XVII, Havana, Editorial de Ciencias Sociales, 2001.

González Vales, Luis, "El Situado Mexicano y la financiación de las fortificaciones de San Juan de Puerto Rico", San Juan, Oficina de Servicios Legislativos de Puerto Rico, 2007. In http://www.oslpr.org/PDFS/SITUADO-MEXICANO-CORR-RCARO-8-FEB-2007.pdf (Accessed February 10, 2015).

Gosse, Philip, The History of Piracy, Mineola, NY, Dover Publications, 2007.

Guerra y Sánchez, Ramiro; Pérez Cabrera, José M.; Remos y Rubio, Juan J. and Santovenia y Echaide, Emeterio, Historia de la nación cubana, Havana, Editorial Historia de la Nación Cubana, X vols., 1952.

Hanke, Lewis, The Spanish Struggle for Justice in the Conquest of America, Philadelphia, University of Pennsylvania Press, 1949.

Haring, C. H., Buccaneers in the West Indies in the XVII Century, New York, E. P. Dutton and Company, 1910.

Hoffman, Paul, The Spanish Crown and the Defense of the Caribbean, 1535-1585, Baton Rouge, Louisiana State University Press, 1980. 
Knight, Franklin W., The Caribbean: The Genesis of a Fragmented Nationalism, New York, Oxford University Press, 1990.

Koot, Christian J., Empire at the Periphery, New York, NYU Press, 2011.

Lane, Kris E., Pillaging the Empire: Piracy in the Americas, 1500-1750, Armonk, New York, M. E. Sharpe, 1998.

Lucena Salmoral, Manuel, Piratas, bucaneros, filibusteros y corsarios en América, Madrid, Mapfre, 1992. Colección MAPFRE 1492.

Marley, David, Wars of the Americas, vol. I, Santa Bárbara, CA, ABC-CLIO, 2008.

Marrero, Leví, Cuba: Economía y Sociedad, vol. III, Madrid, Playor, 1975.

Masefield, John, On the Spanish Main, London, Methuen \& Co., 1906.

Morales-Carrión, Arturo, Puerto Rico and the Non-Hispanic Caribbean, Río Piedras, Editorial de la Universidad de Puerto Rico, 1974.

Moreno Fraginals, Manuel, Cuba/España, España/Cuba: historia común, Barcelona, Editorial Crítica, 1995.

Newquist, Ingrid Marion, "Contraband in the Convento? Material Indications of Trade Relations in the Spanish Colonies", L. Antonio Curet and Mark W. Hauser (eds.), Islands at the Crossroads, Tuscaloosa, University of Alabama Press, 2011: 87-103.

Núñez Sánchez, Carlos, "Relaciones comerciales entre Sevilla y América, 1600-1670”, Ana Olivera Gutiérrez (ed.), Tres siglos de intercambios entre Europa y América, México D. F., Fondo de Cultura Económica, 1994: 378-420.

Parker, Geoffrey, "Spain, Her Enemies and the Revolt of the Netherlands 1559-1648", Past and Present, 49 (Oxford, Reino Unido, November 1970): 72-95.

Pérotin-Dumon, Anne, "French, English and Dutch in the Lesser Antilles: From Privateering to Planting, c. 1560-c. 1650”, Piet C. Emmer and Germán Carrera Damas (eds.), General History of the Caribbean, volume II, London, Unesco Publishing, 1999: 114-158.

Sainz, Nicasio Silverio, Cuba y La Casa de Austria, Miami, Ediciones Universal, 1972.

Scarano, Francisco A., "Imperial Decline, Colonial Adaptation: The Spanish Islands during the Long 17th Century", Stephan Palmié and Francisco A. Scarano, (eds.), The Caribbean: A History of the Region and Its People, Chicago, University of Chicago Press, 2011: 177-189.

Universidad de Sevilla, "De cómo Sevilla fue puerto y puerta de Indias", Alma Mater Hispalense, http://personal.us.es/alporu/histsevilla/sevilla_puerto.htm (Accessed February 10, 2015).

Williams, Eric, From Columbus to Castro: The History of the Caribbean, New York, Vintage Books, 1970. 
Wright, Irene A., The Early History of Cuba, New York, Macmillan, 1916.

Wright, Irene A., Historia documentada de San Cristóbal de La Habana en el siglo XVI, vol. I, Havana, Impresora El Siglo XX, 1927.

Wright, Irene A., “The Dutch and Cuba, 1609-1643”, HAHR, IV/4 (1921): 597-634.

Fecha de recepción: 10 de septiembre de 2014.

Fecha de aceptación: 21 de noviembre de 2014.

\section{Más allá de la línea de demarcación: piratas, corsarios, bucaneros y colonos invasores en Cuba y el Caribe (1529-1670)}

Este ensayo estudia la interconexión entre las guerras en Europa y una variedad de formas de incursión en el Caribe durante el siglo XVI y XVII. Con atención espacial a sucesos en la isla de Cuba este estudio recorre la evolución de actividades piraticas y la creación y desarrollo de colonias no-españolas y el establecimiento de enclaves bucaneros. Este también provee un análisis sistemático sobre el impacto de los conflictos europeos en la cuenca del Caribe. Por último, aquí se exploran los mecanismos defensivos españoles, tales como la militarización, construcción de fortificaciones y el establecimiento del sistema de flotas.

Palabras Clave: piratas; bucaneros; Caribe; colonización; Cuba; esclavos; fortificaciones; guerras; Sistema de flotas. 